\title{
Water as Global Social Policy-International Organizations, Resource Scarcity, and Environmental Security
}

\author{
Jeremy J. Schmidt
}

\section{INTRODUCTION}

If you pick up a book on water politics-practically any book on the topic - you are almost certain to find a claim like this: water doesn't obey political boundaries. Usually, the quick inference is that water conflicts are likely; a logical step that combines the fact that water began flowing eons before politics were around to be obeyed with the political reality that many international borders operate with varying degrees of reference to scarce water resources. An arguably more interesting point, however, is the leitmotif such claims convey. Namely, that global water policy requires an effective combination of space and politics. Among the potential combinations, several leading contenders populate a wide literature. There are spaces of empires, nations, states, mega-cities, agricultural regions, watersheds (or river basins), local communities, Indigenous peoples and, increasingly, aquatic ecosystems themselves. Opposite these, politics

J. J. Schmidt $(\bowtie)$

Department of Geography, Durham University, Durham, UK

e-mail: jeremy.schmidt@durham.ac.uk

(C) The Author(s) 2021

275

K. Martens et al. (eds.), International Organizations in Global

Social Governance, Global Dynamics of Social Policy, https://doi.org/10.1007/978-3-030-65439-9_12 
crisscross state sovereignty, treaties, rights, customs, Indigenous laws, technical criteria, infrastructure, economics, guesswork, and in some cases, equity. Intersections of space and politics anchor two aims of this chapter. The first is to map how International Organizations (IOs) have shaped, and continue to shape, global water policy. The second is to consider how IOs have influenced global discourses. These two aims support a more ambitious argument: that water be treated as global social policy - not as merely instrumental to the public management of social risks in other domains.

This chapter has four sections: The first defends a key premise of the argument that water is social and not only natural. The second maps the historical role IOs have played in colonial and state hydrological programs. Here, IOs actively shaped key parameters of what it meant to act internationally on water policy. This affected the subsequent rise of global water policy. The third identifies the role of IOs in driving discourses of global water policy, particularly those of scarcity and security that link the environmental, economic, and political risks connected to water. Here, there are similarities with other environmental areas where Cold War scientific networks collaborated with IOs to forge global approaches to social policy through hybrid networks of epistemic authority. But there are also important differences owing to how IOs critiqued early approaches to sustainable development for inadequate attention to water. This catalyzed efforts to make water central to social and industrial policy, largely through what is known as integrated water resources management (IWRM). That project reached its height in the 1990s. The fourth section focuses on how, as IWRM waned, IOs redeployed their influence to govern considerations of risk and security in response to global environmental change and economic crises. This approach now dominates global water discourse and demands critique regarding for whom water has become a domain of global social policy.

\section{SOCIAL WATER}

Water is not taught as something that is social. In fact, only a small fraction of the diagrams used to represent Earth's water cycle in textbooks include humans (15\%) and even fewer (2\%) identify human impacts on the global water system (Abbott et al. 2019). This is a serious oversight. Humans have been appropriating more than half of the annual available freshwater since 1995 and have pushed the hydrological cycle so far off balance that 
it no longer operates within the normal bounds of variability (Postel et al. 1996; Milly et al. 2008). The upshot is that the image most people have in their heads of the global water cycle - implicit in much of water policy is deeply flawed. Water does not flow carefree through an eternal, stable cycle of evaporation, condensation, and precipitation from the oceans through the atmosphere and back to earth. To that image, we must add a growing litany of ways in which humans short-circuit water systems: microplastics in raindrops, pharmaceutical loading in rivers, tens of thousands of mega-dams, increased water vapor from climate change, glaciers and ice sheets in rapid retreat, a warming and increasingly acidic ocean, severe droughts, and monsoons that by turns fail to materialize or intensely burst in ways not previously experienced.

How can we think of water in social terms? Anthropologists have described water as a "total social fact" owing to how it is not only biophysically necessary for social life, but also constitutive of multiple institutions of social life (economic, religious, health) such that decisions in one domain cannot be cleanly parsed from others (Orlove and Caton 2010, 402). Part of this has to do with the materiality of water itself and the fact that it is shared by upstream and downstream communities, cities, and nations. Another aspect, however, is water's position amid social norms. For instance, access to water, such as for household connections, often functions as the material and social site for making demands on the state for public goods, and even for citizenship itself (von Schnitzler 2016; Anand 2017). Anthropologists are not alone in their assessment of water as not wholly social but not only natural. Geographers and many others have similarly studied the constitutive role of water in social relations. Recently, this approach has also been extended to connect the practices of scientists and hydrologists to global discourses (Schmidt 2017; Dry 2019). This provides a route to think about water both socially and globally and, I argue here, to consider the historic role of IOs in forging these links. Among the earliest attempts to think of water globally and socially was by Julian Huxley $(1935,1943)$, the enthusiastic eugenicist and United Nations Educational, Scientific and Cultural Organisation's (UNESCO) first Director-General, who lauded the Tennessee Valley Authority (TVA) in the United States for its model of integrating water control and social policy across education, health, and rural development. Huxley thought the TVA a model for UNESCO itself. The most influential instance of water as social policy, however, is surely cost-benefit analysis, which was given its original expression in the 1936 Flood Control Act in the United 
States before it went on to become virtually ubiquitous in social, economic, and environmental policy (Porter 1995; Kysar 2010).

Understanding water socially also provides resources for examining contests and conflicts. It does so by virtue of identifying how different social practices - legal, economic, scientific, religious - are themselves not free of the material constraints water sets: it evaporates, it gets polluted, it flows, it floods, it erodes infrastructure, it squirrels away across property boundaries, and it is variable in its distribution over space and time. As a result, politics are not external to the practices that give an account of where water is and when. That we can think of water socially, however, still requires an approach to doing so. Mine will become evident throughout the chapter (see Schmidt 2017) as one set against popular versions of social constructivists in which water is wholly social; a hydrosocial cycle such as Linton $(2010,3)$ proposes when he argues that "Water is what we make of it." Water can be many things, but a flouter of physics is not among them. As a result, centering the material account of water is key. Where does this leave us with respect to the politics of international organizations? First, we can follow others who have laid the groundwork for thinking of IOs in the water sector as entangled with social conflict, contests, and discourses not sufficiently captured by theories of rational decision making (Conca 2006; cf. Murphy 1994). Second, we can recognize that, like other domains of global social policy, changes in the water sector frequently pace changes in global governance generally. Here, we can extend Abbott et al.'s (2016) analysis of how structures of global governance shift to also think about their material undercurrents. To do so, this chapter contests the premise of historically powerful actors that water be treated non-socially - as merely a 'natural resource'-in the first place (Schmidt 2017; Scott 1998).

\section{From River Basin Organizations to Global IOs: Historical ConteXt}

Historically, water IOs are of two main types. One is populated by international river basin organizations (RBOs) that are spatially oriented to transboundary waters shared by two or more countries. Often, though not always, these are organized according to the physical space that directs water flows - the river basin or watershed. Owing to the diversity of these political and spatial environments, RBOs exhibit considerable variety, 
diversity, and levels of authority (see Schmeier 2012; Lautze et al. 2013). Some operate at the level of treaties, others advise (officially or unofficially) on technical or economic concerns, some are imposed, still others limp along. RBOs often reflect regional and transnational power relations that establish discursive and material hegemony - hydro-hegemony - over transboundary waters (Mirumachi 2015; Warner et al. 2017). There are presently over $120 \mathrm{RBOs}$ that operate on 110 international watercourses worldwide; a tally dutifully kept in an open-access database by Oregon State University's Program in Water Conflict Management and Transformation. ${ }^{1}$ In 1997, the UN Watercourses Convention was adopted to provide international norms regarding the use and conservation of water crossing international borders. This was accomplished largely by codifying existing utilitarian norms as the basis for pursuing equitable water sharing arrangements (Blatter and Ingram 2001). Where did these norms come from? A second group of IOs played a key role. This group includes actors more familiar to other domains of global social policy and which also influenced RBOs, such as the World Bank. These IOs are not constrained to watersheds or state territories, and often are explicitly oriented to projects advantageous to global industry, agricultural trade, and finance. In this section, and as Fig. 12.1 illustrates, I provide a snapshot of how $\mathrm{RBO}$ experiences and IO interactions influenced one another and how both began to shift when 'global' water policy began to take shape with the launch of UNESCO's International Hydrological Decade.

Projects of state-making often exercised control over water as a constitutive aspect of spatial rule. These projects could have international dimensions if either water itself crossed existing borders between states or when colonial powers appropriated water elsewhere. Mitchell (2002) argues that colonial thinking about water, space, and politics continues to exert contemporary influence. He's correct. The draining of marshes for farmland and cities, the damming and straightening of rivers, and the establishment and maintenance of irrigation infrastructure all provide the material evidence for the moral ordering of water under different state-making projects (Scott 1998; Pisani 2002; Blackbourn 2006; Pritchard 2011; Gilmartin 2015; Pietz 2015). When these state-making projects were exported to colonies they remade landscapes and social relationships (Mitchell 2002; D'Souza 2006; Bhattacharyya 2018). In so doing,

\footnotetext{
${ }^{1}$ See: https://transboundarywaters.science.oregonstate.edu/content/international-riverbasin-organization-rbo-database. Accessed March 21, 2020.
} 


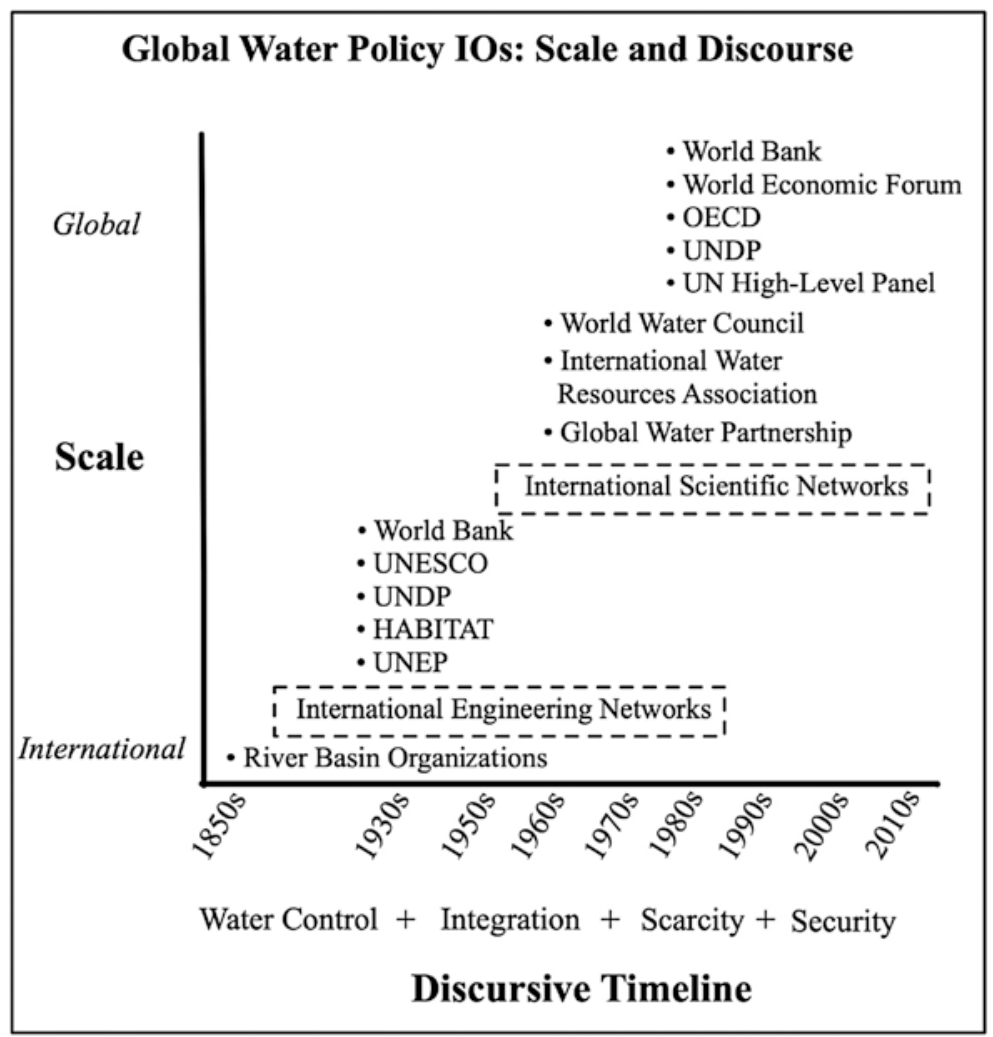

Fig. 12.1 Global water policy IOs: scale and discourse

colonialism exported not only techniques for controlling water, but also an approach to water politics aligned to Eurocentric, racialized notions of the 'international' constituted by recognition and reciprocity among sovereign nations (Pitts 2018).

For instance, as Yao (2019) shows, 'control over nature' was central to how the 'international' was constituted in nineteenth century debates over civilization and progress. These debates stem from the first international RBO: the Danube Commission established in 1856. The Danube Commission was especially occupied with whether Russia's lack of territorial control over the Danube River met (or did not meet) the Eurocentric 'standard of civilization' (Yao 2019). A peculiar, if not quite universal 
feature of applying the so-called 'standard of civilization' was the predominance of engineering as both a practice and disposition to reconciling water with political boundaries. One can only control nature with the right tools, and engineering was a main one. There were many complicating factors to using engineering as a kind of social test, especially owing to the challenges that arose when water control required technical feats that engineering hadn't yet mastered (Mukerji 2009). But there were advantages to using engineering for social ends because it was the kind of expertise that could travel. Facilitated by colonial networks like those of the Dutch and British, engineers shaped and reshaped landscapes across the Middle East, and South and South East Asia (Fasseur 1992; Amrith 2018). Beyond overt colonialism, engineering became a key practice for harnessing water in ways that aligned standards of civilization premised on the 'control of nature' with the spatialization of 'international' water politics. In short, to qualify for reciprocal international agreements was to be able to engineer control over water.

The emergence of transnational water engineering expertise in the late nineteenth and early twentieth centuries gave rise to a diverse set of discursive and technical practices for states and for RBOs (Teisch 2011). Owing to considerable diversity across RBOs (see Mukhtarov and Gerlak 2013), I focus not on the historical contingencies of individual RBOs but rather on how state-making projects began to intersect with the IOs that act globally. The Indian case provides an excellent example: The first major hydrological project after India gained independence from Britain was a multi-purpose river basin development scheme for irrigation, electricity, and flood control in West Bengal. The Damodar Valley Corporation (still in operation today) established the idea of a 'nationalist engineer' as one who controlled water in lockstep with advancing national Indian identity (Klingensmith 2007). The explicit organizational model for the Damodar Valley Corporation was the TVA of the United States, a factor that mattered critically in a conflict over the Indus River on the eastern side of India with neighboring Pakistan in 1951. In that case, tensions over how to share the Indus river were at fever pitch after the World Bank struggled to broker a deal between the two nations. Then, the second director of the TVA, David Lilienthal, managed to get both parties to the table, in part by appealing to the American model of development as a common discourse for multi-purpose river basin planning (Mason and Asher 1973; Ekbladh 2010; Gilmartin 2015). 
In the Indus case, a shared ethos of water control and state identity helped shoulder the burden of international negotiation that allowed expertise from the TVA to first shape 'nationalist' engineers in India and then broker an RBO mediated by the World Bank. The Indian case was not entirely unique. Post-WWII, America's TVA was exported to dozens of countries as the quintessential model of 'international development' promoted by UN agencies, such as UNESCO (see Scott 2006; Ekbladh 2010). Notably in the Mekong River in Southeast Asia, the TVA provided a key organizational model (Biggs 2006; Ekbladh 2010). In 1957, the United Nations Economic Commission for Asia and the Far East backed the creation of the Mekong Committee (later the Interim Mekong Committee) following the independence of Cambodia, Laos PDR, and Vietnam from France (Matthews and Schmidt 2014). The creation of an $\mathrm{RBO}$ on the Mekong subsequently went through different permutations as the seven countries making claims to the river sought - or were compelled to seek - an international coordinating organization (Gardner 1997; Biggs 2011). The cases of the Indus and Mekong also speak to a larger dynamic in which the control of water was increasingly connected to broader, global discourses about international coordination for development.

One effect of using the river basin, or watershed, as the spatial scale for RBOs was the emergence of a discourse on integrated river basin planning by the United Nations (1958; White 1957). Driven by the insight that it is better to coordinate the use of shared waters than not to, RBOs and IOs soon developed a shared discourse of integration. However, and as even a quick perusal of the University of Oregon's RBO database reveals, the organizational structure, funding mechanisms, and economic and datasharing agreements among RBOs vary widely and do not easily reveal a straightforward model of 'integration' (cf. Schmeier 2012). This diversity posed challenges for fostering international norms of integration for RBOs, exemplified by the fact that it took four decades until the UN convention on watercourses was adopted in 1997. It may be too strong to draw direct causal links, but that convention was made more likely as the result of IOs who moved RBO discourses on 'integration' from the international sphere to the global. 


\section{IOs and Global Water Policy}

The shift from international to global water politics officially began in 1977 with the United Nations Conference on Water in Mar del Plata, Argentina. The impetus for the 1977 conference was not water control per se, but rather an integrated global approach to water that individual states had no prospect of controlling. Namely, the cumulative effects of water use that could affect the global water cycle itself. A decade earlier, that concern had been the catalyst for hydrologists in the United States to propose an International Hydrological Decade (IHD), which was convened by UNESCO from 1965-74. The IHD operated, like many international scientific networks during the Cold War, by appealing to - indeed establishing notions of - scientific objectivity presumed independent of national interests (cf. Reisch 2005; Wolfe 2018). Directed by the American Raymond Nace, the IHD combined Russian hydrological expertise with an expansive network of international engineers and scientists. It was through the IHD, in fact, that hydrology 'came of age' as a science, as Nace (1980) would later put it. In this section, I outline how, as the search for 'integration' moved from the international to the global, existing IOs evolved and new IOs began to populate global water policy.

Although UNESCO formally convened the IHD, it also reached out to the World Meteorological Organization (previously known as the International Meteorological Organization). Again, space and politics combined to socially affect water as international scientific collaborations established and standardized the field of global hydrology. This time, as Nace $(1967,550)$ captured at the outset of the IHD, the issue was that water challenges were "a global problem with local roots." That is, a challenge of linking local temporal and spatial variability at the scale of individual watersheds to the global water cycle. The task of IHD scientists was to link these scales objectively. Indeed, the goal was to fit scientific hydrology with universal categories, such as those implied by Nace's (1969) interim report entitled Water and Man: A World View. Supporting this project, a raft of reports told similar stories of 'water and man' and the universal co-evolution of hydrology and societies. These did not displace the racial categories entrained in the 'international' and instead universalized human-water histories in more teleological fashion, where evolution toward global water politics naturally reflected social progress (e.g. Biswas 1970; Fitzsimmons and Salama 1977). 
At the mid-point of the IHD, in 1971, a new expert IO was created. The International Water Resources Association (IWRA) evolved out of the American Water Resources Association and held its first World Water Congress in 1973 in Chicago. The IWRA quickly became a key global knowledge broker as its epistemic community helped forge the emerging discourse of global water policy through meetings and its journal, Water International, which it launched in 1975. By the end of the IHD, in 1974, the familiar empirical picture of the hydrological cycle critiqued above - lacking people - had quantified the global water system. After the IHD ended, a series of international events and actors began to prepare for the 1977 UN Conference on Water in Mar del Plata. The IWRA, as well as the International Institute of Environment and Development (also founded in 1971) began to partner with global organizations such as UNESCO, HABITAT, and the World Bank to orient global water governance toward a dual assessment of water's global distribution as mapped against human needs. At Mar del Plata, these two pillars provided the basis for a new discourse of water scarcity that ported the scientific objectivity of global hydrology over to social policy. The putatively objective basis of the new discourse on water scarcity provided a way to incorporate the engineering of water control with social policy in what was known as Rational Planning (Biswas 1978). Rational Planning was not unique to water (see Lindblom 1999), but in this sector it used water's statistical variability in any particular state as the basis for decision making. These statistical distributions continue to travel widely and have been rehearsed innumerable times in descriptions of the Earth's water, in which oceans account for around $97 \%$ of the total water on the planet, freshwater only $3 \%$. Of the latter, most is locked in ice or deep underground, with the remaining freshwater comprising a scarce reservoir that ought to be managed rationally to achieve utilitarian ends of maximum well-being. This empirical account was bolstered by the water atlas published by UNESCO just after the IHD ended (Korzoun et al. 1978).

Discourses of water scarcity established in Mar del Plata arrived just prior to the widespread adoption of neoliberal policies that sought an enhanced - in some versions exclusive - role for free markets in environmental sectors. At Mar del Plata, similar ideas were in circulation as the idea of water scarcity was interpreted by the World Bank as requiring forms of water pricing to enhance conservation (Warford 1978). As neoliberal policies were applied in structural adjustment programs in Chile and elsewhere in the 1980s (often supported by the World Bank and other parties 
to the 'Washington Consensus') they became a live testing ground that produced mixed results not only for privatization but also for discourses of global water policy (Bauer 2004; Goldman 2005; Boelens et al. 2010). Through discourses of water scarcity, however, an emerging role for water specific IOs arose. By this time, the International Water Resources Association had convened its World Water Congress several times since its inaugural launch in the 1970s, and routinized meetings involving scientists, government officials, and non-governmental organizations met every 2 or 3 years. This meant that when neoliberalism hit the ground there was already an established global network of water expertise intersecting with other IOs such as the World Bank or the United Nations Environment Programme (UNEP) (see Schmidt 2017).

The IWRA proved a critical IO in the 1980s, especially in its response to the 1987 World Commission on Environment and Development report, Our Common Future, also known as the Brundtland Report on sustainable development. Members of the IWRA (1991) critiqued Our Common Future for what they perceived as insufficient attention to water issues. Then, determined not to let the upcoming opportunity to put water on the sustainable development agenda at Rio de Janeiro in 1992 pass, they organized a preliminary meeting in Dublin. The conference produced what are known as the "Dublin Principles," which concretized neoliberal policies in many respects by declaring that water "has an economic value in all its competing uses and should be recognized as an economic good" (Dublin Statement 1992, np). The principle came fourth in a list, and as a way to integrate water's environmental importance, the need for participatory forms of management, and the unique role of women in provisioning and safeguarding water under conditions of scarcity. It also became a flashpoint of conflict and contest as IOs began to push the idea of integrated water resources management, or IWRM, based on the Dublin Principles into global sustainability agendas.

Through IOs like the World Bank, UNESCO, and the IWRA, the idea of IWRM became virtually hegemonic in the 1990s as a way to integrate human and environmental water uses while maximizing human well-being (Conca 2006). The upshot of IWRM's 'integration' of global hydrology and water pricing was congruent with what Bernstein (2001) described as the "liberal compromise" of sustainable development: the promotion of markets as the most effective instrument for environmental relief. This compromise solidified further in the 1990s through the creation of new IOs that carried both a technical and social remit, such as the Global Water 
Partnership (GWP) in 1996. The Global Water Partnership (2000) soon established itself as a key knowledge broker through a series of influential Technical Reports on IWRM that argued water was both a social and economic good (Rogers et al. 1998). The GWP continues to play a key role in promoting IWRM worldwide as it has expanded to include over 3000 partner organizations in 183 countries. The same year, the World Water Council was launched. An outcome of a special session at the IWRA World Water Congress in 1994, this new IO sought more direct political influence for the water sector in global economic and environmental policy. It quickly launched its own journal, Water Policy, to help establish credibility as a multi-stakeholder convenor and also began to convene triennial World Water Forums. Its editor-in-chief, Jerome Delli Priscoli (2000), explicitly sought to naturalize 'integration' in the water sector; he claimed it arose from a universal human longing to return to the comfort of the womb.

\section{Water IOs: From IWRM to Global Social Risks}

At the turn of the new millennium, water IOs took stock. Many of the projects promoting IWRM were faltering, often critiqued for weighting technical criteria of water control too heavily and not paying sufficient attention to social contexts or institutions (Blomquist and Schlager 2005; Dellapenna and Gupta 2008). Even for the World Bank (2004) IWRM had lost its luster, not least owing to backlash against water privatization and social resistance to neoliberalism (see Olivera 2004). Adding further urgency was the 2006 United Nations Development Program (2006) report on the inequitable connections of water scarcity, social power, and poverty. The ensuing reappraisal of IWRM, however, also took place in a context where humans were altering the global water system (Schmidt 2013). The rational approach to water scarcity soon incorporated emerging, adaptive approaches to resource management and governance as well as emerging discourses of water security to bridge from existing IWRM programs to structural governance changes (Cook and Bakker 2012). Here, water's materiality once again constrained and compelled policy responses.

Established IOs and new intervenors navigated the challenge of institutional inertia around IWRM - including development and financing commitments - and efforts to reckon with new social and biophysical realities. The IWRA continued convening the World Water Congress while the World Water Council hosted its World Water Forum. The World Water 
Forums in the Hague (2000) and Kyoto/Shiga/Osaka (2003) brought together experts and government ministers to align the water sector with the sustainability agenda then taking shape around the Millennium Development Goals. Experts in the water sector, however, were beginning to wonder openly whether the discursive consensus of IWRM and water scarcity were enough, or effective (Biswas 2004; Gleick and Lane 2005). A significant element of the discontent was unease about the conceptual lock-in of IWRM at a time when evidence was mounting that humans were increasingly driving the global hydrological cycle - both through direct, large-scale appropriation of water and through indirect changes to land cover and the global climate system (see Vörösmarty et al. 2004). Several factors led, in fairly rapid succession, to a decade of intense transformation in how IOs affected global water policy: (1) The World Economic Forum established itself as an independent assessor of progress toward the Millennium Development Goals in 2004, and soon began publishing annual risk reports on the state of "global risks" (Schmidt and Matthews 2018). (2) Energy and food price shocks in the years preceding the 2008 global financial crisis led Ban Ki-moon to ask the World Economic Forum to focus on water security at the 2009 meeting in Davos. (3) This led to the World Economic Forum (2011) using its discursive influence to establish water security as linked to shared structural risks linking across what is now known as the water-energy-food nexus (Schmidt and Matthews 2018; cf. Pigman 2007). Together, these changes added to notions of water scarcity a growing recognition of water security that prompted IOs in global water policy to shift away from efforts to use water as the material basis for 'integrating' various domains of social policy. Instead, the water-energy-food nexus established a different normative basis; water was already integrated across multiple social policy domains that produced systemic risks to the global water cycle and to the global economy. As such, the task of policy was to govern this form of integration; or what the World Economic Forum (2011) described as the structural undervaluation of water in the global economy.

Established IOs such as the Global Water Partnership responded to these changes by renovating existing institutional stances. For instance, the GWP built on its earlier report on Water as a Social and Economic Good and its defense of the Dublin Principles in 1998 through a new technical report on Water Financing and Governance amid the 2008 global financial crisis (Rogers et al. 1998; Rees et al. 2008). Indeed, paralleling the broader financialization of the global economy (see Krippner 2012), 
the water sector turned to financial tools for global water policy, such as the use of credit risk ratings, debt-for-water swaps, microcredit schemes and infrastructure financing to address issues of water security across the water-energy-food nexus (see Kolker et al. 2016; Schmidt and Matthews 2018). The Global Water Partnership (2012) made special use of resilience to link the systemic risks to water-energy-food nexus and the global economy. Here, the water sector paced broader policy discourses that had adopted the language resilience after the 2008 financial crisis to bridge environmental and economic risks (Cooper 2011). Responses to energy, food, climate and financial crises, however, were not sufficient: The Millennium Development Goal for water and sanitation was not met. Worldwide, billions of people still lack basic sanitation infrastructure and hundreds of millions lack access to clean, reliable drinking water.

In 2010, the United Nations passed the Human Right to Water and Sanitation. The landmark agreement created a key moment for IOs and for states, many of whom had drifted toward (if they had not already embraced) enhanced uses of market mechanisms in the water sector. The response of IOs created new contests, particularly as new networks like the World Economic Forum engaged with large corporate actors (PepsiCo, Coca-Cola, Nestlé) to forge new working groups, such as the 2030 Working Group, that sought input into the Sustainable Development Goals. While civil society organizations interpreted the Human Right to Water and Sanitation as a clear victory over privatization and other neoliberal agendas, many global IOs took the view that the best way to deliver on the right to water was through the market. Here, World Bank programs on "water for all" that had established transnational policy expertise sought to capture the right to water and to channel it into existing structures of political economy (Goldman 2009). Debates over the right to water continue, especially as different approaches to utilizing the right are mobilized across different legal and social contexts (see Langford and Russell 2017; Sultana and Loftus 2020).

A final, further twist was added to the field of IOs as the OECD (2013, 2017) began to position itself with respect to water security, global governance, and the nexus of land, water, and energy. The OECD had long had an interest in water and governance, and its increased attention to the portfolio came just as the UN created the High-Level Panel on Water as part of its efforts to develop political momentum to deliver on the 2015 Sustainable Development Goals. Here, water policy reflected shifts in global governance that increasingly use 'goals' or targets to steer both 
states and markets (see Kanie and Biermann 2017). The UN High-Level Panel likewise used the language of resilience to describe complex systems in terms of responses to disturbance, and as being subject to critical thresholds, shocks, and tipping-points. These descriptions of interconnected economic and environmental systems mirrored the discourse of the Sustainable Development Goals, where resilience was increasingly used to link global environmental risks to the sustainability agendas (e.g. Sachs 2015). From 2016 to 2018, the UN High-Level Panel on Water completed its first major initiative on "valuing water" and committed to the human right to water while positioning that right amid discourses of enhancing resilience across economic and environmental systems (Schmidt 2020). In so doing, the High-Level Panel did not, as originally hoped, get through the bricolage of global water contests. Instead, it has reaffirmed the central discourses IOs have developed and employed by naturalizing the form of 'integration' achieved under neoliberal programs through which human impacts on the global water cycle, and the Earth system in general, have been amplified (see also Schmidt 2019).

\section{CONCLUSION}

IOs have played multiple, critical roles in global water policy. There is much more to be researched and examined about them - water continues to disobey political boundaries. The aim of this chapter has been to argue for a treatment of water as global social policy. To do so requires tracking the architecture of arguments through which a particular and powerful social view of water has come to dominate global water governance through discourses of control, integration, scarcity, and security. This has involved IOs working in multiple ways to: negotiate international agreements, facilitate international scientific collaborations, define integrated approaches to water management, and to align water with emerging development agendas in the context of economic and environmental crises.

There are many dissenting narratives occluded from, and deliberately excluded by, the current architecture of global water governance. The upshot is that the water risks faced by those marginalized in intersectional ways across both urban and rural areas, and in view of colonial histories and ongoing settler colonial structures, remain unaddressed. And this is only to constrain the explication of risks to our own species. One implication of the foregoing argument is that further, critical study of water as global social policy is paramount to reckoning with the social power that 
continues to be wielded through control over it. A second is that, in order to follow through on not treating water as merely instrumental to other policy domains, it is essential to confront the material reality that multiple other domains - such as health, education, and industry - are interdependent with water. So, it will not do to think of water non-socially, nor to hope we can make whatever we like out of water. Rather, it is imperative to treat water as not only natural and not wholly social, and to develop an architecture for global social policy capacious enough to govern water equitably.

\section{REFERENCES}

Abbott, Benjamin, Kevin Bishop, Jay Zarnetske, C. Minaudo, F.S. Chapin III, Stefan Krause, D. Hannah, L. Conner, D. Ellison, S.E. Godsey, S. Plont, J. Marçais, T. Kolbe, A. Huebner, R. Frei, T. Hampton, S. Gu, M. Buhman, S. Sayedi, O. Ursache, M. Chapin, K. Henderson, and G. Pinay. 2019. "Human Domination of the Global Water Cycle Absent From Depictions and Perceptions." Nature Geoscience 12: 533-540.

Abbott, Kenneth, Jessica Green, and Robert Keohane. 2016. "Organizational Ecology and Institutional Change in Global Governance." International Organization 70 (2): 247-277.

Amrith, Sunil. 2018. Unruly Waters: How Mountain Rivers and Monsoons Have Shaped South Asia's History. London: Allen Lane.

Anand, Nikhil. 2017. Hydraulic City: Water and the Infrastructures of Citizenship in Mumbai. Durham: Duke University Press.

Bauer, Carl. 2004. Siren Song: Chilean Water Law as a Model for International Reform. Washington DC: Resources for the Future.

Bernstein, Steven. 2001. The Compromise of Liberal Environmentalism. New York: Columbia University Press.

Bhattacharyya, Debjani. 2018. Empire and Ecology in the Bengal Delta: The Making of Calcutta. Cambridge: Cambridge University Press.

Biggs, David. 2006. "Reclamation nations: the U.S. Bureau of Reclamation's role in water management and nation-building in the Mekong Valley, 1945-1975." Comparative Technology Transfer and Society 4 (3): 225-246.

Biggs, David. 2011. Quagmire: Nation-building and nature in the Mekong Delta. Washington: University of Washington Press.

Biswas, Asit. 1970. History of Hydrology. Amsterdam: North-Holland Publication Co.

Biswas, Asit. ed. 1978. United Nations Water Conference: Summary and Main Documents. Oxford: Pergamon Press. 
Biswas, Asit. 2004. "From Mar Del Plata to Kyoto: A Review of Global Water Policy Dialogues." Global Environmental Change 14 (Supplement): 81-88.

Blackbourn, David. 2006. The Conquest of Nature: Water, Landscape, and the Making of Modern Germany. New York: W.W. Norton \& Company.

Blatter, Joachim, and Helen Ingram, eds. 2001. Reflections on Water: New Approaches to Transboundary Conflict and Cooperation. Cambridge: Massachusetts Institute of Technology.

Blomquist, William, and Edella Schlager. 2005. "Political Pitfalls of Integrated Watershed Management." Society and Natural Resources 18 (2): 101-117.

Boelens, Rutgerd, David Getches, and Armando Guerva-Gill, eds. 2010. Out of the Mainstream: Water Rights, Politics and Identity. London: Earthscan.

Conca, Ken. 2006. Governing water: contentious transnational politics and global institution building. Cambridge: MIT Press.

Cook, Christina, and Karen Bakker. 2012. "Water Security: Debating an Emerging Paradigm.” Global Environmental Change 22 (1): 94-102.

Cooper, Melinda. 2011. "Complexity Theory After the Financial Crisis." Journal of Cultural Economy 4 (4): 371-385.

Dellapenna, Joseph, and Joyeeta Gupta, eds. 2008. The Evolution of the Law and Politics of Water. Dordrecht: Springer.

Dublin Statement. 1992. "The Dublin Statement on Water and Sustainable Development." http://www.wmo.int/pages/prog/hwrp/documents/english/icwedece.html. Accessed February 10, 2020.

Dry, Sarah. 2019. Waters of the World. London \& Chicago: Scribe Publications \& University of Chicago Press.

D'Souza, Rohan. 2006. Drowned and Dammed: Colonial Capitalism and Flood Control in Eastern India. New Delhi: Oxford University Press.

Ekbladh, David. 2010. The Great American Mission: Modernization and the Construction of an American World Order. Princeton: Princeton University Press.

Fasseur, Cornelis. 1992. The Politics of Colonial Exploitation: Java, the Dutch, and the Cultivation System. Ithaca: Southeast Asia Program, Cornell University.

Fitzsimmons, Stephen, and Ovadia Salama. 1977. Man and Water: A Social Report. Boulder: Westview Press.

Gardner, Lloyd C. 1997. "From the Colorado to the Mekong." In Vietnam: the early decisions, edited by Lloyd C. Gardner \& Ted Gittinger, 37-57. Austin: University of Texas Press.

Gilmartin, David. 2015. Blood and Water: The Indus River Basin in Modern History. Oakland: University of California Press.

Gleick, Peter, and John Lane. 2005. "Large International Water Meetings: Time for a Reappraisal." Water International 30 (3): 410-414.

Global Water Partnership Technical Advisory Committee. 2000. Integrated Water Resources Management. Stockholm: Global Water Partnership. 
Global Water Partnership. 2012. Water Security and Climate Resilient Development: Technical Background Document. Stockholm: Global Water Partnership.

Goldman, Michael. 2005. Imperial Nature: The World Bank and Struggles for Justice in the Age of Globalization. New Haven: Yale University Press.

Goldman, Michael. 2007. "How 'Water for All!' Policy Became Hegemonic: The Power of the World Bank and Its Transnational Policy Networks." Geoforum 38 (5): 786-800.

Goldman, Michael. 2009. "Water for All! The Phenomenal Rise of Transnational Knowledge and Policy Networks." In Environmental Governance: Power and Knowledge in a Local-Global World, edited by Gabriela Kütting, and Ronnie D. Lipschutz, 145-169. New York: Routledge.

Huxley, Julian. 1935. "Plans for Tomorrow: The Tennessee Valley Authority." The Listener November 897-900.

Huxley, Julian. 1943. TVA: Adventure in Planning. Cheam, Surrey: The Architectural Press.

International Water Resources Association. 1991. Sustainable Development and Water: Statement on the WCED Report Our Common Future. In Water: The International Crisis, edited by Robin Clarke, 182-185. London: Earthscan Publications Ltd.

Kanie, Norichika, and Frank Biermann, eds. 2017. Governing Through Goals: Sustainable Development Goals as Governance Innovation. Cambridge: MIT Press.

Klingensmith, Daniel. (2007). 'One valley and a thousand': Dams, nationalism, and development. Oxford: Oxford University Press.

Kolker, Joel E., Bill Kingdom, Sophie Trémolet, James Winpenny, and Rachel Cardone. 2016. Financing Options for the 2030 Water Agenda. Washington, DC: World Bank.

Korzoun, V.I., A.A. Sokolov, M.I. Budyko, K.P. Voskresensky, G.P. Kalinin, A.A. Konoplyantsev, E.S. Korotkevich, and M.I. Lvovich, eds. 1978. Atlas of World Water Balance: Water Resources of the Earth. Paris: UNESCO.

Krippner, Greta R. 2012. Capitalizing on Crisis: The Political Origins of the Rise of Finance. Cambridge: Harvard University Press.

Kysar, Douglas. 2010. Regulating From Nowhere: Environmental Law and the Search for Objectivity. New Haven: Yale University Press.

Langford, Malcolm, and Anna F.S. Russell, eds. 2017. The Human Right to Water: Theory, Practice, and Prospects. Cambridge: Cambridge University Press.

Lautze, Jonathan, Kai Wegerich, Jusipbek Kazbekov, and Murat Yakubov. 2013. "International River Basin Organizations: Variation, Options, and Insights." Water International 38 (1): 30-42.

Lindblom, Charles. 1999. “A Century of Planning.” In Planning Sustainability, edited by K.M. Meadowcroft, 39-65. New York: Routledge. 
Linton, J. 2010. What is Water? The History of a Modern Abstraction. Vancouver: UBC Press.

Mason, Edward S., and Robert E. Asher. 1973. The World Bank Since Bretton Woods. Washington DC: The Brookings Institution.

Matthews, Nate, and Jeremy Schmidt. 2014. "False Promises: The Contours, Contexts and Contestation of Good Water Governance in Lao PDR and Alberta, Canada." International Journal of Water Governance 2 (2/3): 21-40.

Milly, P.C.D., J. Betancourt, M. Falkenmark, R.M. Hirsch, Z.W. Kundzewicz, D.P. Lettenmaier, and R.J. Stouffer. 2008. "Stationarity is Dead: Whither Water Management?" Science 319: 573-574.

Mirumachi, Naho. 2015. Transboundary Water Politics in the Developing World. London: Routledge.

Mitchell, Timothy. 2002. Rule of Experts: Egypt, Techno-Politics, Modernity. Berkeley: University of California Press.

Mukerji, Chandra. 2009. Impossible Engineering: Technology and Territoriality on the Canal Du Midi. Princeton: Princeton University Press.

Mukhtarov, Farhad, and Andrea K. Gerlak. 2013. "River Basin Organizations in the Global Water Discourse: An Exploration of Agency and Strategy." Global Governance 19 (2): 307-326.

Murphy, Craig. 1994. International Organization and Industrial Change: Global Governance Since 1850. Cambridge: Polity Press.

Nace, Raymond L. 1967. "Water Resources: A Global Problem With Local Roots." Environmental Science and Technology l (7): 550-560.

Nace, Raymond L. 1969. Water and Man: A World View. Paris: UNESCO.

Nace, Raymond L. 1980. "Hydrology Comes of Age: Impact of the International Hydrological Decade." EOS 61 (53): 1241-1242.

OECD. 2013. Water Security for Better Lives. Paris: OECD Publishing.

OECD. 2017. The Land-Water-energy Nexus: Biophysical and Economic Consequences. Paris: OECD Publishing.

Olivera, Oscar. 2004. Cochamaba! Water War in Bolivia. Cambridge, MA.: South End Press.

Orlove, Ben, and Steven Caton. 2010. "Water Sustainability: Anthropological Approaches and Prospects." Annual Review of Anthropology 39: 401-415.

Pigman, Geoffrey A. 2007. The World Economic Forum: A Multi-Stakeholder Approach to Global Governance. London: Routledge.

Pietz, David A. 2015. The Yellow River: The Problem of Water in Modern China. Cambridge: Harvard University Press.

Pisani, Donald J. 2002. Water and American Government: The Reclamation Bureau, National Water Policy, and the West, 1902-1935. Berkeley: University of California Press.

Pitts, Jennifer. 2018. Boundaries of the International: Law and Empire. Cambridge: Harvard University Press. 
Porter, Theodore, M. 1995. Trust in Numbers: The Pursuit of Objectivity in Science and Public Life. Princeton: Princeton University Press.

Postel, Sandra, Gretchen Daily, and Paul Ehrlich. 1996. "Human Appropriation of Renewable Fresh Water.” Science 271 (5250): 785-788.

Priscoli, Jerome. 2000. "Water and Civilization: Using History to Reframe Water Policy Debates and to Build a New Ecological Realism." Water Policy 1 (6): 623-636.

Pritchard, Sara B. 2011. Confluence: The Nature of Technology and the Remaking of the Rhône. Cambridge: Harvard University Press.

Rees, Judith, James Winpenny, and Alan W. Hall. 2008. Water Financing and Governance: Tec Background Papers, No. 12. Stockholm: Global Water Partnership.

Reisch, George A. 2005. How the Cold War Transformed Philosophy of Science: To the Icy Slopes of Logic. Cambridge: Cambridge University Press.

Rogers, Peter, Ramesh Bhatia, and Annette Huber. 1998. Water as a Social and Economic Good: How to Put the Principle Into Practice, Volume 2: Technical Advisory Committee Background Papers. Stockholm: Global Water Partnership.

Sachs, Jeffrey D. 2015. The Age of Sustainable Development. New York: Columbia University Press.

Schmeier, Susanne. 2012. Governing International Watercourses: River Basin Organizations and the Sustainable Governance of Internationally Shared Rivers and Lakes. London: Routledge.

Schmidt, Jeremy J. 2013. "Integrating Water Management in the Anthropocene." Society and Natural Resources 26 (1): 105-112.

Schmidt, Jeremy J. 2017. Water: Abundance, Scarcity, and Security in the Age of Humanity. New York: New York University Press.

Schmidt, Jeremy J. 2020. "Valuing Water: Rights, Resilience, and the UN HighLevel Panel on Water." In Water Politics: Governance, Justice, and the Right to Water, edited by Farhana Sultana, and Alex Loftus, 15-27. London: Routledge.

Schmidt, Jeremy J. 2019. "The Moral Geography of the Earth System." Transactions of the British Institute of Geographers 44 (4):721-734.

Schmidt, Jeremy J., and Nathanial Matthews. 2018. "From State to System: Financialization and the Water-Energy-food-climate Nexus." Geoforum 91: $151-159$.

Scott, James. 1998. Seeing like a state: how certain schemes to improve the human condition have failed. New Haven: Yale University Press.

Scott, James. 2006. "High modernist social engineering: the case of the Tennessee Valley Authority." In Experiencing the State, edited by Lloyd. I., Rudolph \& John K. Jacobsen, 3-52. Oxford: Oxford University Press.

Sultana, Farhana, and Alex Loftus, eds. 2020. Water Politics: Governance: Justice, and the Right to Water. London: Routledge. 
Teisch, Jessica B. 2011. Engineering Nature: Water, Development, of the Global Spread of American Environmental Expertise. Chapel Hill: University of North Carolina Press.

United Nations. 1958. Integrated River Basin Development: Report By a Panel of Experts. New York: UN Department of Economic and Social Affairs.

United Nations, Economic Commission for Asia and the Far East. 1957. Development of Water Resources in the Lower Mekong Basin. Bangkok: United Nations.

United Nations Development Program. 2006. Beyond Scarcity: Power, Poverty and the Global Water Crisis. New York: United Nations Development Programme. von Schnitzler, Antina. 2016. Democracy's Infrastructure: Techno-Politics and Protest After Apartheid. Princeton: Princeton University Press.

Vörösmarty, Charles J., D. Lettenmaier, C. Lévqêue, M. Meybeck, C. Pahl-Wostl, J. Alcamo, W. Cosgrove, H. Grassl, H. Hoff, P. Kabat, F. Lansigan, R. Lawford, and R. Naiman. 2004. "Humans Transforming the Global Water System." EOS 85: 513-516.

Warford, J.J. 1978. Pricing as a Means of Controlling the Use of Water Resources. In Water Development and Management: Proceedings of the United Nations Water Conference, Vol. 2, edited by Asit K. Biswas, 659-684. New York: Pergamon Press.

Warner, Jeroen, Naho Mirumachi, Rebecca Farnum, Mattia Grandi, Filippo Menga, and Mark Zeitoun. 2017. "Transboundary 'Hydro-Hegemony': 10 Years Later." WIREs Water 4 (6): el242, 1-13.

White, Gilbert. 1957. "A Perspective of River Basin Development." Law and Contemporary Problems 22 (2): 157-188.

Wolfe, Audra. 2018. Freedom's Laboratory: The Cold War Struggle for the Soul of Science. Baltimore: John Hopkins University Press.

World Bank. 2004. Water Resources Sector Strategy: Strategic Directions for World Bank Engagement. Washington DC: World Bank.

World Economic Forum. 2011. Water Security: The Water-Food-Energy-Climate Nexus. Washington, DC: Island Press.

Yao, Joanne. 2019. “'Conquest from barbarism': the Danube Commission, international order and the control of nature as a Standard of Civilization." European Journal of International Relations 25 (2): 335-359. 
Open Access This chapter is licensed under the terms of the Creative Commons Attribution 4.0 International License (http://creativecommons.org/licenses/ by $/ 4.0 /$ ), which permits use, sharing, adaptation, distribution and reproduction in any medium or format, as long as you give appropriate credit to the original author(s) and the source, provide a link to the Creative Commons licence and indicate if changes were made.

The images or other third party material in this chapter are included in the chapter's Creative Commons licence, unless indicated otherwise in a credit line to the material. If material is not included in the chapter's Creative Commons licence and your intended use is not permitted by statutory regulation or exceeds the permitted use, you will need to obtain permission directly from the copyright holder.

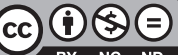

